и предварительный прогноз притока воды в крупные водохранилища во втором квартале [Электронный pecypc] // http://meteoinfo.ru/hydro-spring.

10. ВолгаИнформ. В Самарской области готовятся к сильному половодью [Электронный ресурс] // http://volgainform.ru/allnews/430801.

11. Исаева М.В. Пространственно-временная изменчивость основных биоклиматических показателей на территории Приволжского федерального округа: автореф. дис. ... канд. геогр. наук. Казань, 2009. C. $14-22$.

12. Склюев В.В., Мозговой Д.П. Особенности поведения и динамика численности лисицы обыкновенной (Vulpes vulpes) в Красноармейском районе Самарской области // Вестник Самар. ГУ. Естественнонаучная серия. 2009. № 2 (68). С. 161-166.

13. Склюев В.В. Особенности перекрывания участков лисицы обыкновенной, существенные при картировании территории // Современные проблемы зоологии позвоночных и паразитологии: мат-лы 3 междунар. науч. конф. «Чтения памяти проф. И.И. Бара-
баш-Никифорова», г. Воронеж, 20-21 марта 2011 г. Воронеж, 2011. С. 288-291.

14. Склюев В.В. Полоспецифичные различия в площадях и размещении индивидуальных участков лисицы обыкновенной // Современные проблемы зоологии позвоночных и паразитологии: мат-лы 4 междунар. науч. конф. «Чтения памяти проф. И.И. Барабаш-Никифорова», г. Воронеж, 13-15 апр. 2012 г. Воронеж, 2012. С. 254-257.

15. Склюев В.В. Избыточность кормовой базы как причина уменьшения площадей индивидуальных участков лисицы обыкновенной // Экология, эволюция и систематика животных: мат-лы междунар. науч.-практ. конф. Рязань, 2012. С. 370-372.

16. Барановская Т.Н., Колосов А.М. Питание лисицы // Зоол. журн. 1935. Т. XIV, вып. 3. С. 523-550.

17. Склюев В.В. Исследование состояния популяции лисицы Красноармейского района Самарской области // Изв. Самар. НЦ РАН. 2009. Т. 11, № 1(4). С. 661-665.

\title{
SNOW COVER AND THE CLIMATE SEVERITY INFLUENCE ON THE COMMON FOX (VULPES VULPES) BEHAVIORAL ADAPTATION
}

\section{(C) 2017}

Skluev Valerij Vitaljevich, candidate of biological sciences, dean of Chemistry and Biology Faculty Sklueva Olga Aleksandrovna, postgraduate student of Ecology and Environmental Protection Department Samara State Regional Academy (Nayanova) (Samara, Russian Federation)

Abstract. One of the ways to adapt to the changing parameters of the environment is behavioral adaptation. The paper presents data on the weather rigidity index use (G. Bodman) in environmental studies. The authors describe the behavioral characteristics of the common fox (Vulpes vulpes, Linnaeus, 1758) activity depending on the amount of snow cover and the climate severity in Krasnoarmeyskiy district of the Samara Region. Relatively low temperature and quite high wind speed influence the heat loss of the animal more than high temperature in calm weather. In scientific literature (A.N. Formozov, 1946, 1990) it's noted that it is possible to use "weather cruelty» indicator that defines the conditions that contribute to frostbite. It is determined by low air temperature and wind velocity that particularly affect cooling objects that have excessive heat in comparison with the environment. However, A.N. Formozov could not use this indicator due to rather large deviations as the wind speed and the temperature on the investigated territory, as even in the same locality there is a discrepancy with the data of weather stations located remotely from each other, this author didn't study habitats independently (A.N. Formozov, 1946, 1990, 2010). At the same time it is also noted that snowfall is an important factor, a powerful element of the environment that indicates what life forms can live in vast areas with snowy winter. Snow cover leads to seasonal migration or switching to food located above the snow.

Keywords: weather rigidity index; harsh climate; snow; environmental studies; common fox (Vulpes vulpes); behavioral activity; behavioral adaptation; Bodman indicator; winter traces of tracking mammals; ecological plasticity.

УДК 58.032

\section{РЕЗУЛЬТАТЫ ГИДРОБОТАНИЧЕСКОГО МОНИТОРИНГА ЧЕРНОВСКОГО ВОДОХРАНИЛИЩА ЗА ПЕРИОД С 1974 ПО 2015 ГОДЫ}

(C) 2017

Соловьева Вера Валентиновна, доктор биологических наук, профессор кафедры биологии, экологии и методики обучения

Самарский государственный социально-педагогический университет (г. Самара, Российская Федераџия)

Аннотащุия. Особенности эксплуатации водохранилищ вызывают необходимость постоянного сбора, анализа и обобщения экологической информации о динамическом состоянии гидроэкосистем с целью прогноза их развития. Важным показателем состояния экосистемы являются процессы зарастания. В работе представлены результаты исследования флоры и растительности Черновского водохранилища в различные годы. Флористическое разнообразие приводится в сравнении с другими водоёмами, гидроботанические данные о которых опубликованы в ряде работ автора статьи. Сравнительный анализ показал, что общий состав флоры водоёмов носит случайный характер, при этом в экологическом спектре отмечается некоторая закономерность, так, для каждого из них характерно небольшое число видов водной флоры и преобладание береговых видов растений. Изучение растительности Черновского водохранилища показало, что за последние 40 лет, с 1974 по 2015 годы, она изменилась по составу доминантов, при этом сохранилось преобладание воздушно- 
водной растительности над водной, но границы произрастания последних заметно расширились. В настоящее время Черновское водохранилище находится на стадии динамического равновесия. При сохранении неустойчивого гидрорежима и импульсивного характера водопользования продолжительность существования водной экосистемы на данной стадии может быть неограниченно долгой. Снижение уровня воды водохранилища может привести к ускорению зарастания и активизации процессов заболачивания.

Ключевые слова: водохранилище; динамика; флора; гидрофиты; гелофиты; гигрогелофиты; гигрофиты; гигромезофиты; мезофиты; растительность; растительные сообщества; фитоценозы; растительный покров.

Природно-климатические особенности степной зоны обусловили создание здесь большого числа гидросооружений. Из общего расхода воды малых рек и их притоков 70-80\% падает на весенний период. Поэтому в условиях интенсивного земледелия ставится задача задержания весеннего паводка, в южных районах Самарской области продолжается строительство капитальных плотин в русле рек и на базе оврагов. Малые водохранилища, созданные в долинах рек и оврагах, оказывают существенное влияние на ландшафты, преобразуя микроклимат, воздействуя на грунтовые воды, почвы, растительность и животный мир. Эколого-экономическое значение малых и небольших водохранилищ, достаточно частые изменения в режиме их эксплуатации вызывают необходимость постоянного сбора, анализа и обобщения экологической информации о динамическом состоянии гидроэкосистем с целью прогноза их развития. Высшая водная и прибрежно-водная растительность экотонной зоны, зоны напряжения, служит монитором функционального состояния экосистем, являясь как показателем нагрузки, так и показателем отклика экосистемы на антропогенное воздействие. В связи с этим они являются объектами гидроботанических исследований.

На территории Самарской области детально изучен растительный покров Ветлянского и Поляковского водохранилищ [1-3]. Исследованы геоэкологические условия и динамика растительного покрова Кутулукского водохранилища [4; 5]. Из водохранилищ Сыртового Заволжья изучен состав флоры Михайло-Овсянского водохранилища [6]. Рассмотрены вопросы динамики флоры и растительности Кондурчинского водохранилища за период 1990-2005 гг. [7]. Объектами гидроботанического изучения были Таловское и Чубовское водохранилища [8; 9].

Мониторинг флоры и растительности Черновского водохранилища ведется с 1974 года [10]. Целью настоящей работы было получение современной картины гидроботанического состава водоёма. В задачи работы входило изучение флоры и растительности и проведение сравнительного анализа экологического спектра флоры изучаемого водоёма с другими водохранилищами Самарской области. При анализе флоры приняты методические подходы В.Г. Папченкова и В.В. Соловьевой [11], т.е. учитывалась не только водная флора (гидрофиты, гелофиты и гигрогелофиты), а флора водоёмов в целом, с включением в нее околоводных видов растений (гигрофитов, гигромезофитов и мезофитов). Идентификация видовых таксонов проводилась с помощью определителя сосудистых растений «Флора водоёмов Волжского бассейна» $[12]$.

Черновское водохранилище расположено на территории Волжского района. Создано оно в 1953 году на базе левобережного притока р. Самары - реке Черной, в 3 км от с. Черноречье. Площадь водосбора

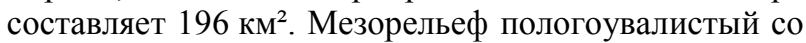

слабой расчлененностью балками и оврагами. Геологические условия однородные. Рельефоформирующими коренными породами являются неоген-четвертичные глинисто-суглинистые и глинисто-супесчаные отложения. Геологической основой служат плейстоцен-голоценовые, аккумулятивные, аллювиальные и аллювиально-озерные отложения (рис. 1). Неотектонические условия равномерные, суммарная амплитуда тектонических движений не превышает $250 \mathrm{~cm}$.

В почвенном покрове преобладают черноземы выщелоченные и типичные, главным образом, среднего и легкого механического состава. Высокая проницаемость грунтов, выходы ключей и родников создают благоприятные условия для круглогодичного питания водохранилища. Пополнение его идет также за счет местного стока весенних вод, кроме того, вода поступает по трубопроводу из реки Самары (водохранилище смешанного типа - наливное и речное).

При минимальном наполнении водоёма его поверхность достигает 455 га. Черновское водохранилище имеет длину до 6 км при ширине около 1 км. Наибольшая глубина составляет 11,6 м. Дно илистое, с примесью песка, мелкозема и растительных остатков. Гидрорежим неустойчивый, амплитуда колебания в разные годы составляет от 1,5 до 2,5 м (рисунок 2). Тренды гидрорежима показывают, что в последние годы для водоёма отмечается небольшое повышение уровня воды, что связано со снижением водопотребления на орошение с 6752 га до 2987 га.

Современные сведения о химическом составе воды по результатам исследований лаборатории Центра мониторинга окружающей среды по Самарской области приведены в таблице 1 .

Водохранилище используется населением для купания и рыбной ловли. На левом берегу расположен дом охотника и рыболова совхоза «Черновский», контролирующий его использование. В 1995 году в водохранилище запущено 130 тысяч годовалых карпов. Кроме того, здесь распространены щука, окунь, сазан, плотва, уклея, которые привлекают к себе любителей рыбной ловли. Водохранилище также служит для орошения сельскохозяйственных угодий и близлежащих дачных массивов, для водопоя крупного рогатого скота.

Впервые флора Черновского водохранилища изучалась сотрудниками кафедры ботаники Куйбышевского педагогического института В.И. Матвеевым и А.М. Зотовым в 1974 году. Тогда было отмечено 66 видов растений из 18 семейств и 46 родов. В процессе изучения водоёма и его побережий в 1989 году было зарегистрировано 79 видов высших растений. Экологический спектр флоры представляли мезофиты - 35 видов, гигрофиты - 17, гигрогелофиты -8 , гелофиты - 8 и гидрофиты - 11 видов растений. В 1989 году не были отмечены виды - Typha laxmannii Lepech. и Alisma lanceolata L. Из гидрофитов ранее не произрастал Potamogeton gramineus L. 


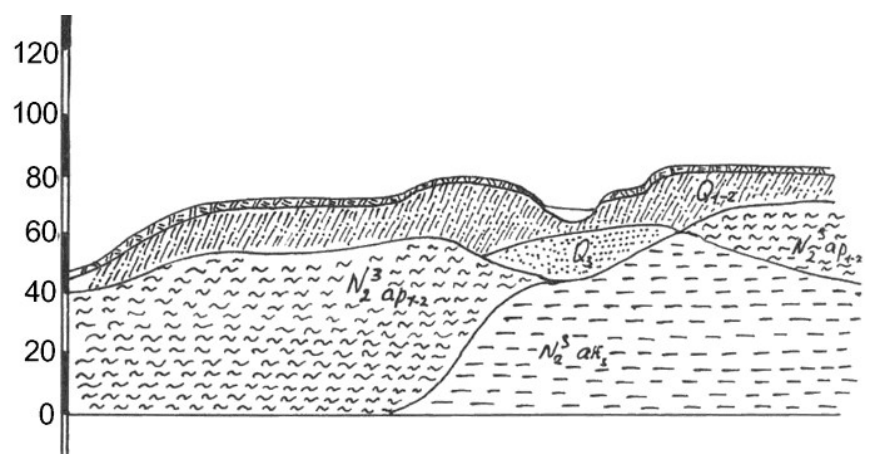

Рисунок 1 - Геоморфологический профиль в районе Черновского водохранилища

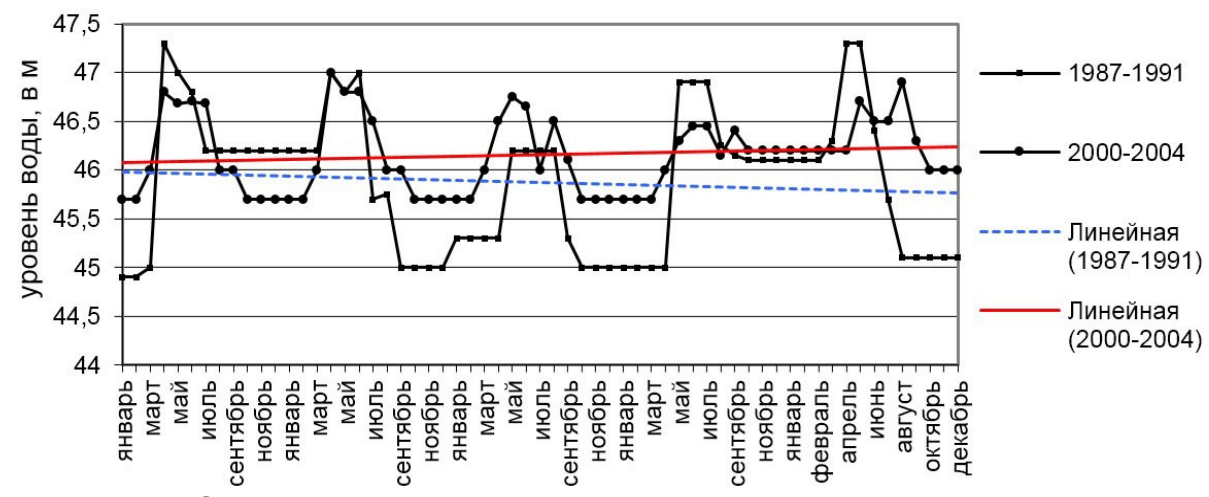

Рисунок 2 - Динамика и тренды гидрорежима Черновского водохранилища

Таблица 1- Гидрохимические показатели воды Черновского водохранилища

\begin{tabular}{|c|c|c|c|c|c|c|c|c|c|c|c|c|c|}
\hline & $\begin{array}{l}\text { Неф- } \\
\text { тепро- } \\
\text { дукты }\end{array}$ & $\begin{array}{l}\mathrm{pH} \\
\text { сре } \\
\text { ды }\end{array}$ & $\begin{array}{c}\text { Раство- } \\
\text { ренный } \\
\text { кисло- } \\
\text { род }\end{array}$ & $\begin{array}{c}\text { Перман- } \\
\text { ганатная } \\
\text { окисляе- } \\
\text { мость }\end{array}$ & БПК & $\begin{array}{c}\text { Су- } \\
\text { хой } \\
\text { оста- } \\
\text { ток }\end{array}$ & $\begin{array}{l}\text { Хло } \\
\text { ри- } \\
\text { ды }\end{array}$ & $\begin{array}{c}\text { Су- } \\
\text { льфа- } \\
\text { ты }\end{array}$ & $\begin{array}{l}\text { Нит } \\
\text { ра- } \\
\text { ты }\end{array}$ & $\begin{array}{c}\text { Каль- } \\
\text { ций } \\
\text { моль/д } \\
\text { м }^{3}\end{array}$ & $\begin{array}{c}\text { Маг- } \\
\text { ний, } \\
\text { моль/д } \\
\text { м }^{3}\end{array}$ & $\begin{array}{c}\text { Гидрок } \\
\text { арбо- } \\
\text { нат, } \\
\text { моль/д } \\
\text { м }^{3} \\
\end{array}$ & \begin{tabular}{|c} 
Общая \\
жест- \\
кость \\
моль/дм \\
3
\end{tabular} \\
\hline у плотины & 0,06 & 8,2 & 10,57 & 3,96 & 2 & 522 & 45 & 79,7 & 0,77 & 3,7 & 5,8 & 6,6 & 9,5 \\
\hline \multirow[t]{2}{*}{$\begin{array}{c}\text { ПДК для во- } \\
\text { доёмов }\end{array}$} & 0,05 & $\begin{array}{l}6,5- \\
8,5\end{array}$ & $\mathrm{He}<6$ & 5 & 3 & 1000 & 300 & 100 & 9,1 & 3,61 & 16 & $5-6, .5$ & 7 \\
\hline & \multicolumn{13}{|c|}{ СанПин 2.1.5.980-00 } \\
\hline
\end{tabular}

После 1989 года во флоре Черновского водохранилища были инвентаризированы Carex acuta L., Scirpus lacustris L., Eleocharis palustris (L.) Roem et Schult), Bolboschoenus koshevnikovii (Litv.) A.E. Kozhevnikov, Mentha arvensis L., Scutellaria galericulata L., Stachys palustris L., Tussilago farfara L., Alopecurus geniculatus L., то есть растения переувлажненных и достаточно увлажненных местообитаний. Ранее на сыром побережье не произрастали Lysimachia vulgaris L., L. nummularia L., Phalaroides arundinacea (L.) Rauschert и другие гигромезофиты.

В результате гидроботанических исследований в июле 2015 г. во флоре Черновского водохранилища зарегистрировано 90 видов растений, из них 12 гидрофитов, по 9 видов гелофитов и гигрогелофитов, 20 гигрофитов и 40 гигромезофитов и мезофитов (рисунок 3). Увеличение числа видов, составляющих основу растительного покрова временно затопляемой части побережья водохранилища происходит, главным образом, за счет гигрофитных и гигромезофитных групп растений. За последние годы появились Potamogeton perfoliatus L., Phragmites altissimus (Benth.) Nabille, Oenanthe aquatica (L.) Poir., Carex melanostachya Bieb ex. Willd., Epilobium hirsutum L., Rorippa austriaca (Crantz.) Bess., Angelica archangelica L., Calystegia sepium (L.) R. Br., Euphorbia palustris L., Rumex stenophyllus Ledeb., Senecio tataricus Less.

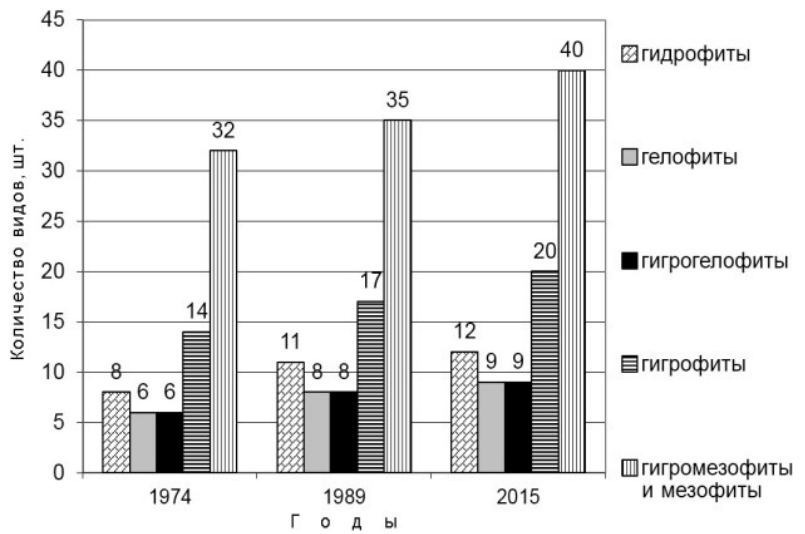

Рисунок 3 - Динамика числа видов растений Черновского водохранилища в различные годы исследований

Сравнение общего состава флоры водохранилищ (таблица 2) показало, что ее формирование имеет случайный характер, зависит от наличия зачатков растений в речном бассейне и агентов распространения диаспор, то есть водоплавающих птиц. Состав гидрофитов в видовом отношении невелик, число видов этой экологической группы колеблется от 5 до $16 \%$. Также закономерным является низкая доля участия гелофитов (от 7 до 20\%) и гигрогелофитов (от 8 до $12 \%$ ). При этом состав гигрофитов в сравнивае- 
мых водоёмах равен от 19 до 37\%, а гигромезофитов и мезофитов - от 17 до $50 \%$.

Математическая обработка сравниваемых списков флор проводилась с использованием коэффициента флористического сходства Жаккара [14]. В результате наибольшее сходство имеют флоры Кондурчинского, Кутулукского и Чубовского водохра- нилищ (57-59\%), расположенных в лесостепной зоне. Наименьшее - Чубовское и Ветлянское водохранилища, созданные в лесостепной и степной зонах. Более высокие коэффициенты сходства имеет водная флора (таблица 3). Так, Кондурчинское, Чубовское, Черновское и Таловское водохранилища по этому комплексу видов имеют сходство 67-72\%.

Таблица 2 - Экологический спектр флоры водохранилищ Самарской области (абсолютное число видов/в \%)

\begin{tabular}{|c|c|c|c|c|c|c|}
\hline \multirow[b]{2}{*}{$\begin{array}{c}\text { Название } \\
\text { водохранилищ }\end{array}$} & \multicolumn{5}{|c|}{ Экологический состав флоры } & \multirow[b]{2}{*}{$\begin{array}{l}\text { Всего } \\
\text { видов }\end{array}$} \\
\hline & Гидрофиты & Гелофиты & $\begin{array}{c}\text { Гигро- } \\
\text { гелофиты }\end{array}$ & Гигрофиты & $\begin{array}{c}\text { Гигромезофиты } \\
\text { и мезофиты }\end{array}$ & \\
\hline Кондурчинское & $12 / 10,7$ & $8 / 7,1$ & $12 / 10,7$ & $30 / 26,8$ & $50 / 44,6$ & 112 \\
\hline Чубовское & $7 / 9,4$ & $9 / 12,2$ & $9 / 12,2$ & $23 / 37,0$ & $26 / 35,1$ & 74 \\
\hline Кутулукское & $12 / 12,3$ & $11 / 11,3$ & $11 / 11,3$ & $20 / 20,6$ & $43 / 44,3$ & 97 \\
\hline Черновское & $12 / 13,3$ & $9 / 10,0$ & $9 / 10,0$ & $20 / 22,2$ & $40 / 44,4$ & 90 \\
\hline Ветлянское & $10 / 16,4$ & $8 / 13,1$ & $5 / 8,1$ & $12 / 19,7$ & $26 / 42,6$ & 61 \\
\hline Большеглушицкое & $3 / 5,1$ & $8 / 13,8$ & $7 / 12,0$ & $11 / 19,0$ & $29 / 50,0$ & 58 \\
\hline Таловское & $10 / 15,4$ & $6 / 9,2$ & $8 / 12,3$ & $13 / 20,0$ & $28 / 43,0$ & 65 \\
\hline Корнеевское & $8 / 13,8$ & $9 / 15,5$ & $7 / 12,0$ & $18 / 31,0$ & $16 / 27,6$ & 58 \\
\hline Гавриловское & $8 / 15$ & $11 / 20,8$ & $8 / 15$ & $13 / 24,5$ & $13 / 24,5$ & 53 \\
\hline Поляковское & $13 / 22,4$ & $10 / 17,2$ & $7 / 12,0$ & $18 / 31,0$ & $10 / 17,2$ & 58 \\
\hline Михайло-Овсянское & $14 / 16,6$ & $12 / 14,2$ & $7 / 8,30$ & $21 / 25,0$ & $30 / 36,0$ & 84 \\
\hline
\end{tabular}

Таблица 3 - Коэффициенты сходства флор водохранилищ Самарской области

\begin{tabular}{|l|c|c|c|c|c|c|}
\hline Названия водоёмов & Кондурчинкое & Чубовское & Кутулукское & Черновское & Ветлянское & Таловское \\
\hline Кондурчинское & & 63 & $\mathbf{6 5}$ & $\mathbf{7 2}$ & 45 & $\mathbf{6 8}$ \\
\hline Чубовское & 51 & & 49 & 57 & 50 & 39 \\
\hline Кутулукское & $\mathbf{5 7}$ & $\mathbf{5 9}$ & & 56 & 43 & 52 \\
\hline Черновское & 49 & 41 & 47 & & 44 & $\mathbf{6 7}$ \\
\hline Ветлянское & 40 & 37 & 38 & 41 & & $\mathbf{6 9}$ \\
\hline Таловское & 50 & 53 & 45 & 49 & 47 & \\
\hline
\end{tabular}

Примечание. В верхней части таблицы значения коэффициента Жаккара для водной флоры, в нижней для флоры в целом.

Растительность Черновского водохранилища за последние 40 лет, с 1974 по 2015 годы, изменилась по составу доминантов, при этом сохранилось преобладание воздушно-водной растительности над водной, но границы произрастания последних заметно расширились.

Среди водной растительности довольно большого развития достигло сообщество рдеста разнолистного, которое ранее на водохранилище отсутствовало. Заросли рдеста гребенчатого и рдеста блестящего встречались только в верховье водохранилища. В последние годы гидрофитные сообщества расселились на различных участках водохранилища, они попрежнему просты по структуре и бедны во флористическом отношении.

Воздушно-водная и водная растительность имеет неравномерное распространение в различных районах акватории. Наибольшее развитие получили формации тростника южного, рогоза узколистного, клубнекамыша морского и осоки острой. В верховьях Черновского водохранилища отмечено сильное зарастание рогозом узколистным и тростником обыкновенным. Формация клубнекамыша морского распространена практически повсеместно на мелководьях в виде узкого пояса шириной 1-5 м. Сообщества воздушно-водной растительности имеют четко выраженный бордюрный характер. Формации типично водных растений имеют пятнистый и фрагментарно-зарослевый характер. Это сообщества рдеста злакового, рдеста гребенчатого и рдеста блестя- щего. Характер зарастания - от сплошного зарослевого в верховье до фрагментарно-пятнистого в приплотинной части. Наибольшее распространение имеет бордюрный тип зарастания. Широкое распространение на мелководьях получили фитоценозы с участием горца земноводного.

Растительность Черновского водохранилища образует экотонные сообщества, расположенные на сыром побережье водоёма и в зонах с кратковременным и длительным затоплением. Фитоценозы побережья представлены неопределенными микрогруппировками сорно-рудеральных видов и луговыми сообществами.

На правобережье распространена прибрежная растительность (асc. Agrostis stolonifera - heteroherbosa), образующее пояс 4-6 м в ширину, а местами до 10-12 м. Высота растений достигает 150 см. Здесь среди таких гигрогелофитов, как полевица побегообразующая, дербенник иволистный, преообладают алтей лекарственный и тысячелистник птармика. Во время описания последние находились в фазе цветения, отчего луг имел бело-розовый аспект. Проективное покрытие $100 \%$. В составе этого сообщества отмечено 25 видов.

Ниже по склону расположен пояс, сформированный осоково-разнотравной ассоциацией (асс. Сагех acuta - heteroherbosa), от 2 до 6-10 м в ширину. Травостой мощный, до 145 см высоты, проективное покрытие $100 \%$. В густых зарослях осоки острой отмечены герань болотная, крестовник татарский, алтей 
лекарственный, тысячелистник птармика и другие виды растений. В местах избыточного увлажнения среди осочника встречаются куртины тростника южного, рогоза узколистного, сусака зонтичного. Под пологом ивняков, кроме перечисленных видов, встречаются вербейник обыкновенный, паслен сладко-горький, лопух паутинистый, чина клубненосная, вербейник монетчатый и другие растения. В местах, где сильно развит древостой, сложенный ивой белой, тополем черным, осиной, отмечены густые заросли крапивы двудомной (acc. Salix alba - Urtica dioica heteroherbosa).

В экотонах влажных лугов в сопровождении древесно-кустарниковой растительности, фитоценозы приобретают лентовидный характер (acc. Elytrigia repens + Zerna inermis - heteroherbosa, acc. Agrostis stolonifera - Potentila anserina + Amoria fragifera). Данные coобщества находятся на верхней границе экотонной зоны. Здесь можно наблюдать плавную смену сообществ в зависимости от почвенного увлажнения.

Прибрежная растительность тоже расположена в виде лент. Пояс поливицево-разнотравной ассоциации (acc. Agrostis stolonifera - heteroherbosa) граничит с ситниково-полевицевой (acc. Agrostis stolonifera - Juncus gerardii), которая имеет ширину до 5 м. Перечисленные фитоценозы и сообщества череды олиственной (acc. Bidens frondosa + Lycopus europeus - heteroherbosa, acc. Bidens frondosa + Lycopus europeus - heteroherbosa) могут находится как на влажном берегу, так и в условиях временного затопления.

В верховье Черновского водохранилища получили развитие сплошные заросли рогоза узколистного, тростника высочайшего и южного (acc. Phragmites altissimus, acc. Phragmites australis).
Прибрежная и воздушно-водная растительность переходного и озеровидного районов Черновского водохранилища представлена поясами фитоценозов, сформированных в условиях временного и длительного затопления. Растительность внешнего пояса образована формацией тростника южного и осоки острой. Заросли осочников в экотонной зоне занимают около 9 га. Внутренний пояс сформирован рогозом узколистным и клубнекамышом морским. Формация клубнекамыша морского распространена практически повсеместно на мелководьях водохранилища (всего около 5 га). Расположение этого сообщества в поясе растительности временного затопления весьма условно, так как эдификатор может произрастать в различных гидрологических условиях - в местах избыточного увлажнения, среди зарослей ив и на мелководьях с глубиной воды до 60 см. Формации рдеста блестящего, рдеста пронзеннолистного, рдеста гребенчатого и рдеста злакового составляют водную растительность. Сообщества водных растений образуют сплошные или прерывистые пояса или пятнистые заросли.

В целом, растительность Черновского водохранилища представлена 13 формациями и 22 ассоциациями, из них 5 формаций и 7 ассоциаций относятся к водной растительности. Наибольшее развитие получила растительность зоны временного затопления (12 ассоциаций). Формация рогоза узколистного и тростниковые заросли занимают 56 и 65 га соответственно. В настоящее время Черновское водохранилище является значительно заросшим, степень зарастания 32\%. Чистая продукция водохранилища по абсолютно-сухому веществу равна 12540 ц в год, что в энергетическом выражении составляет 2290 МДж в год (таблица 4).

таблица 4 - Фитопродукция Черновского водохранилища (степень зарастания 32\%)

\begin{tabular}{|c|c|c|c|c|c|c|c|c|c|}
\hline Формации & $\begin{array}{c}\text { Пло- } \\
\text { щадь } \\
\text { заро- } \\
\text { слей, } \\
\text { га }\end{array}$ & $\begin{array}{c}\text { Сырая } \\
\text { надзем- } \\
\text { ная фи- } \\
\text { томасса, } \\
\text { кг/м² }\end{array}$ & $\begin{array}{c}\text { Абсо- } \\
\text { лютно } \\
\text { сухая } \\
\text { надзем- } \\
\text { ная фи- } \\
\text { томаса } \\
\text { кг } / \mathrm{M}^{2}\end{array}$ & $\begin{array}{c}\text { Запасы } \\
\text { абсо- } \\
\text { лютно- } \\
\text { сухой } \\
\text { надзем- } \\
\text { ной фи- } \\
\text { томассы } \\
\text { ц в год }\end{array}$ & \begin{tabular}{|c|} 
Коэффи- \\
циент для \\
расчета \\
продукции \\
по фито- \\
массе \\
\end{tabular} & \begin{tabular}{|c|} 
Чистая \\
продук- \\
ция, по \\
абсо- \\
лютно- \\
сухому \\
веще- \\
ству, ц в \\
год \\
\end{tabular} & $\begin{array}{c}\text { Чистая } \\
\text { продукция } \\
\text { по органи- } \\
\text { ческому } \\
\text { веществу, } \\
\text { кг/м² в год }\end{array}$ & $\begin{array}{c}\text { Чистая про- } \\
\text { дукция в } \\
\text { энергетиче- } \\
\text { ском выра- } \\
\text { жении, } \\
\text { кДж/м² в } \\
\text { год }\end{array}$ & $\begin{array}{c}\text { Чистая про- } \\
\text { дукция на } \\
\text { площадь за- } \\
\text { рослей в } \\
\text { энергетиче- } \\
\text { ском выра- } \\
\text { жении, } \\
\text { МДж в год }\end{array}$ \\
\hline $\begin{array}{l}\text { Agrosteta } \\
\text { stoloniferae }\end{array}$ & 2,1 & 0,80 & 0,34 & 71,4 & 2,3 & 164 & 0,28 & 14533 & 30,5 \\
\hline $\begin{array}{l}\text { Bolboschoen } \\
\text { eta maritimi }\end{array}$ & 5,3 & 1,63 & 0,39 & 209,4 & 2,3 & 48 & 0,33 & 15065 & 79,8 \\
\hline $\begin{array}{l}\text { Cariceta } \\
\text { acutae }\end{array}$ & 8,7 & 2,83 & 0,54 & 468,1 & 2 & 936 & 0,50 & 16394 & 142,6 \\
\hline $\begin{array}{l}\text { Typheta an- } \\
\text { gustifoliae }\end{array}$ & 56,1 & 3,36 & 0,59 & 3309,9 & 1,2 & 3972 & 0,55 & 16483 & 924,7 \\
\hline $\begin{array}{l}\text { Phragmiteta } \\
\text { australis }\end{array}$ & 65,3 & 1,63 & 0,90 & 5903,1 & 1,2 & 7084 & 0,85 & 16660 & 1087,9 \\
\hline $\begin{array}{l}\text { Persicarieta } \\
\text { amphibii }\end{array}$ & 2,8 & 1,26 & 0,23 & 64,4 & 2,5 & 161 & 0,21 & 16128 & 5,8 \\
\hline $\begin{array}{l}\text { Potameta } \\
\text { gramineus }\end{array}$ & 0,8 & 2,1 & 0,12 & 9,6 & 2,5 & 24 & 0,09 & 13293 & 10,6 \\
\hline $\begin{array}{l}\text { Potameta } \\
\text { pectinati }\end{array}$ & 2,4 & 2,1 & 0,15 & 35,5 & 2,5 & 89 & 0,12 & 14179 & 34,0 \\
\hline $\begin{array}{l}\text { Potameta } \\
\text { perfoliati }\end{array}$ & 1,5 & 1,75 & 0,16 & 24,6 & 2,5 & 62 & 0,13 & 14356 & 2,2 \\
\hline Всего & 145 & & & & & 12540 & & & 2290 \\
\hline
\end{tabular}


В результате проведенных исследований можно сделать вывод, что в настоящее время Черновское водохранилище находится на стадии динамического равновесия [15]. При сохранении неустойчивого гидрорежима и импульсивного характера водопользования продолжительность существования водоёма на данной стадии может быть неограниченно долгой. Снижение уровня может привести к ускорению зарастания и активизации процессов заболачивания.

\section{СПИСОК ЛИТЕРАТУРЫ:}

1. Соловьева В.В., Матвеев В.И. Флора и растительность Ветлянского водохранилища // Интродукция, акклиматизация, охрана и использование растений. Куйбышев: Изд-во Куйб. гос. ун-та, 1991. С. 3246.

2. Соловьева В.В., Дамрин А.Г. Закономерности формирования растительного покрова Поляковского водохранилища // Вопросы степеведения. Влияние экспозиции склона и литологии на структуру и динамику пастбищно-степных ландшафтов: научн. докл. и мат-лы школы-семинара молодых ученыхстепеведов в рамках ФЦП «Интеграция». Оренбург, 2002. C. 79-84.

3. Соловьева В.В., Дамрин А.Г., Плаксина Т.И., Чибилев А.А., Петрищев В.П. Ландшафтно-геоботанические особенности формирования геосистем малых водохранилищ (на примере Поляковского водохранилища) // Поволжский экологический журнал. 2003. № 2. C. 109-118.

4. Соловьева В.В. Геоэологические условия и динамика растительного покрова Кутулукского водохранилища // Известия Самарского научного центра РАН. Т. 8, № 1. Спец. выпуск «Актуальные вопросы экологии», вып. 5. 2006. С. 316-331.

5. Соловьева В.В. Растительность Кутулукского водохранилища // Фиторазнообразие Восточной Европы. 2006. № 2. С. 17-30.

6. Соловьева В.В. Фиторазнообразие искусственных водоёмов Сыртового Заволжья // Степи Северной Евразии: мат-лы IV междунар. симпозиума. Оренбург: ИПК «Газпромпечать», 2006. С. 685-688.
7. Соловьева В.В. Динамика флоры и растительности Кондурчинского водохранилища за период 1990-2005 гг. // Современные проблемы ботаники: мат-лы конф., посв. памяти В.В. Благовещенского. Ульяновск, 28 февраля - 1 марта 2007 г. Ульяновск: УлГПУ, 2007. С. 183-192.

8. Соловьева В.В. Итоги гидроботанического изучения Таловского водохранилища за период 19902006 гг. // Изучение растительных ресурсов Волжско-Камского края: сборник научных трудов. Чебоксары, 2010. Вып. 1. С. 83-86.

9. Соловьева В.В. Структура и динамика растительного покрова Чубовского водохранилища // Структурно-функциональная организация и динамика растительного покрова: мат-лы Всерос. науч.практ. конф. с междунар. участием, посвящ. 100летию д.б.н. проф. В.Е. Тимофеева. Самара: ПГСГА, 2012. С. $50-54$.

10. Соловьева В.В., Матвеев В.И. Основные закономерности формирования флоры и растительности Черновского водохранилища // Вопросы экологии и охраны природы в лесостепной и степной зонах: межвед. сб. научн. тр. Самара, 1995. С. 193-197.

11. Папченков В.Г., Соловьева В.В. Флора прудов Среднего Поволжья // Самарская Лука: Бюллетень. 1993. № 4. С. 172-190.

12. Лисицына Л.И., Папченков В.Г., Артеменко В.И. Флора водоёмов Волжского бассейна: Определитель сосудистых растений. М.: Товарищество научных изданий КМК, 2009. 219 с.

13. Атлас земель Самарской области. «Московское аэрогеодезическое предприятие» Федеральной службы геодезии и картографии России / под ред. Н.И. Порошиной. 2002. 99 с.

14. Василевич В.И. Статистические методы в геоботанике. Л.: Наука, 1969. С. 11-124.

15. Соловьева В.В. Условия устойчивого развития управляемых гидроэкосистем // Синергетика природных, технических и социально-экономических систем: сборник статей междунар. науч.-техн. конф. (8-9 ноября 2007 г.): в 2 ч. Ч. 1. Тольятти: ТГУС, 2007. C. $110-118$.

\title{
RESULTS OF CHERNOVSKOE RESERVOIR HYDRO BOTANICAL MONITORING FROM 1974 TO 2015
}

(C) 2017

\author{
Solovieva Vera Valentinovna, doctor of biological sciences, \\ professor of Biology, Ecology and Methods of Teaching Department \\ Samara State University of Social Sciences and Education (Samara, Russian Federation)
}

Abstract. Features of reservoirs use make it necessary to collect, analyse and synthesise environmental information about the state of hydroecosystems with a purpose of their development forecast. Overgrowing processes are an important indicator of ecosystem. The following paper contains the results of the study of Chernovskoe reservoir flora and vegetation in different years. Floristic diversity is compared with other reservoirs and hydro botanic information about them has already been published in a number of the author's papers. The comparative analysis has shown that the overall composition of reservoirs flora is random, while there is some regularity in the environmental spectrum - each of them is characterized by a small number of aquatic species and by the dominance of coastal plant species. The study of Chernovskoe reservoir vegetation has shown that the composition of dominants has changed over the past 40 years, from 1974 to 2015 . There is a dominance of air water vegetation above the water one, but the borders of the water vegetation growth have widened. Chernovskoe reservoir is currently in dynamic equilibrium. The lifetime of aquatic ecosystem at this stage may be unlimited if there is an unstable hydro regime and impulsive character of water use. The reservoir water level lowering may lead to overgrowth and accelerate activation of waterlogging.

Keywords: reservoir; dynamics; flora; hydrophytes; helophytes; hygrohelophytes; hygrophytes; hygromesophytes; mesophytes; vegetation; plant communities; phytocenosis; vegetation cover. 